\title{
RANCANGAN RUANGAN KERJA YANG SEHAT DI ERA KEBIASAAN BARU DENGAN TEKNOLOGI COVID BUSTER SESUAI PERATURAN MENTERI KESEHATAN PMK 1077 TAHUN 2011
}

\author{
Healthy Workspace Design in a New Habit Era with Covid Buster Technology in \\ Accordance with the Minister of Health Regulation PMK 1077- 2011
}

\author{
Suharto Ngudiwaluyo', R. Djoko Goenawan ${ }^{2}$, Sudarmin $^{3}$, Rizky A. Purnama ${ }^{4}$ dan Amos Lukas ${ }^{5}$ \\ 1,3,4,5 Pusat Sistim Audit Teknologi - BPPT- JI.MH. Thamrin No. 8 Jakarta \\ ${ }^{2}$ Balai Besar Teknologi Modifikasi Cuaca - BPPT- JI.MH. Thamrin No. 8 Jakarta \\ E-mail: amos@bppt.go.id
}

\begin{abstract}
Abstrak
Corona virus telah menjadi pandemi dunia, termasuk di Indonesia. Untuk mencegah penyebaran corona virus bisa dilakukan dengan menyegarkan udara yang sehat, segar dan ramah lingkungan yaitu udara dengan kadar anion yang memenuhi standar kesehatan, melalui Teknologi Covid Buster. Produktivitas kerja harus kembali berjalan dengan tata cara (protokol) yang baru selain mencuci tangan secara rutin, pemakai masker dan penggunaan hand sanitizer, hal lainnya adalah penyediaan udara yang sehat di dalam ruangan kerja yang memenuhi standar kesehatan dan pemda. Ion negatif (anion) mengandung sebuah elektron ekstra. Ion negatif yang mampu membersihkan udara rumah dari berbagai alergen seperti debu, virus, spora, bahkan bisa terbasmi bakteri dan virus (covid). Anion dihirup dapat meningkatkan kadar anion dalam darah, dapat meningkatkan anti-inflamasi dan imunitas, sehingga pegawai yang bekerja di dalam runagan lebih meningkat kekebalan tubuhnya dan dapat meningkat produktivitas kerjanya. Kadar anion $1.000 / \mathrm{cm}^{3}-2.000 / \mathrm{cm}^{3}$ baik untuk kesehatan, $5.000 / \mathrm{cm}^{3}-50.000 / \mathrm{cm}^{3}$ dapat meningkatkan kekebalan tubuh, $50.000 / \mathrm{cm}^{3}-100.000 / \mathrm{cm}^{3}$ dapat membunuh kuman dan mengurangi infeksi, kadar $100.000 / \mathrm{cm}^{3}-500.000 / \mathrm{cm}^{3}$ dapat membantu tubuh dalam proses penyembuhan alami. Teknologi Covid Buster mampu menghasilkan kadar anion sebesar 2-100 juta/cm3/detik dari sumbernya, hingga ke sudut ruangan hingga terukur lebih dari 6 juta anion, pada jarak radius 2-3 meter dan baik untuk terapi dan menyembuhkan penyakit, serta udara diruangan menjadi steril dan sehat, bahkan pada jarak 4-6 meter masih memiliki kandungan 1-5 juta/ $\mathrm{cm}^{3}$.
\end{abstract}

Kata Kunci: Covid-19, Teknologi Covid Buster, Anion, Udara sehat, Kebiasan baru

\begin{abstract}
.
Corona virus has become a world pandemic including in Indonesia, to prevent the spread of Corona virus can be done by providing healthy air, fresh and environmentally friendly i.e. air with anion level that meets health standards, through Covid Buster technology. Working Producvititas need to re-walk with new procedures in addition to regular hand washing, mask usage and using hand sanitizer, one of which is providing healthy air in the working room that meets the regulations of government-issued health standards. Negative ions (anions) contain extra electrons, which are negative ions that can clean the house air from various allergens such as dust, viruses, spores, and can even eradicate bacteria and viruses (covid). Inhalation anions Increase the level of anions in the blood, increase antiinflammatory and immunity, so that employees who work in the runagan increase their immunity so that their productivity increases. The level of anion $1,000 / \mathrm{cm}^{3}-2,000 / \mathrm{cm}^{3}$ good for health, $5,000 / \mathrm{cm}^{3}-50,000 / \mathrm{cm}^{3}$ can increase immunity, 50,000 - 100,000/cm3 can kill germs and reduce infections, levels $100,000 \mathrm{~cm}^{3}-500,000 / \mathrm{cm} 3$ can help the body in the natural healing process. Covid Buster Technology produces an anion rate of 2-100 million/ ${ }^{\mathrm{m} 3} / \mathrm{second}$ from its source, up to the corner of the room to be measured by more than 6 million anions, at a radius of 2-3 meters and both for therapeutic and curing diseases, as well as the indoor air becomes sterile and healthy, even at a distance of 4-6 meters still has a content of 1-5 million $/ \mathrm{cm}^{3}$
\end{abstract}

Key Words: Covid-19, Covid Buster Technology, Anion, Healthy Air, New Normal 


\section{PENDAHULUAN}

Pada akhir 2019, sekelompok pasien di diagnosa mengalami pneumonia dengan penyebab yang tidak diketahui muncul di wilayah di $\mathrm{Hu}$, Provinsi Hubei China, yang saat ini disebut Corona Virus (2019-nCoV) atau dikenal juga dengan Corona Virus Desease atau CoViD-19 (Zhu et al, 2020), telah ditetapkan sebagai pandemik oleh WHO pada 11 Maret 2020.

Karakteristik Covid-19, terdiri dari ikatan RNA polaritas plus, beramplop di keliling peplomer glikoprotein, pada amplop terdapat lemak hingga mudah dihancurkan oleh disinfekan (khususnya hanya amplopnya), intiDNAnya masih bisa berkembangbiak dan bermutasi lagi, berbentuk pleomorfik / sperik 80 $120 \mathrm{~nm}$, panjang genom $30 \mathrm{~kb}$, ujung -5" bertudung dan ujung -3 " poliadenilasi, dan tidak semua coronavirus bersifat zoonosis. Struktur Covid-19 pada Gambar 1 (Jin et al, 2020).

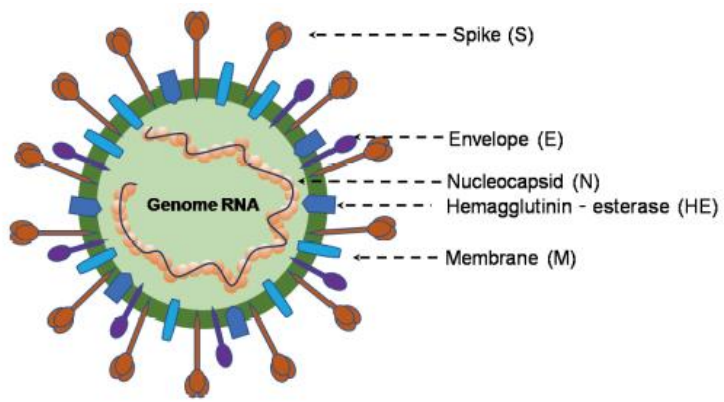

Gambar 1. Struktur Corona Virus Desease (Jin et al, 2020).

Sebaran Covid-19, bisa melalui droplet dari penderita ketika batuk atau bersin, pada kondisi kepadatan virus yang tinggi dapat menyebar secara aerosol-airborne selama beberapa jam sampai beberapa hari di ruang tertutup dan ber-AC (Doremalen et al, 2020). Jangkaun droplet dari virus bisa mencapai diameter 2 meter dan jangkauan aerosol lebih dari 2 meter (Setti et al, 2020).

Secara umum virus respiratory ditularkan melalui tetesan (droplet) termasuk SARS Corona Virus (SARS-CoV), virus influenza, adenovirus, rhinovirus, RSV dan virus parainfluenza dan virus yang ditularkan melalui aerosol termasuk virus rubeola dan virus cacar air (varicella-zoster virus). Sekali batuk, mengeluarkan sekitar 3000 droplet, dengan kecepatan $80 \mathrm{~km} / \mathrm{jam}$ sedangkan bersin dengan kecepatan $320 \mathrm{~km} / \mathrm{jam}$, yang bisa lolos dan berterbangan, kita tahu bahwa satu droplet saja diperkirakan mencapai 200 juta partikel virus (Xie et al, 2007).

Penyebaran virus Covid-19 dipengaruhi oleh suhu dan kelembaban, setiap kenaikan suhu $1^{\circ} \mathrm{C}$ akan terjadi pengurangan kasus baru sebesar $3.08 \%$ dan setiap kenaikan 1\% kelembaban $(\mathrm{RH})$ kasus harian baru berkurang $0,85 \%$ (Wu et al, 2020).

Ion negative (anion) pada dasarnya adalah sekumpulan atom oksigen yang mengandung sebuah elektron ekstra. Ion negatif dapat membantu membersihkan udara rumah dan ruangan dari berbagai alergen seperti debu, spora serta dapat membasmi bakteri, virus dan kuman (Goldstein, 2002).

Anion di sekitar air terjun Niagara sebesar 100.000/cm ${ }^{3}$ (Stroud, 2009), sementara sinar kosmik (uaranium, radium dan thorium) hanya sekitar $500-1.000$ anion per $\mathrm{cm}^{3}$ (Jiang et al, 2018).

Dari hasil penelitian, anion dalam udara yang terhirup paru ${ }^{2}(15 \%)$ dan masuk ke pori pori kulit $(85 \%)$ bisa meningkatkan kadar anion dalam darah, dapat meningkatkan anti-inflamasi dan imunitas serta sel-sel darah menjadi aktif (Tikhonov et al, 2004), bahkan orang sakit berangsur-angsur menjadi sembuh dan yang sehat semakin menjadi lebih sehat.

Beberapa efek biologis dari Anion antara lain meningkatkan kesehatan manusia dan hewan (Krueger and Reed, 1976), menghilangkan polutan udara, menyegarkan dan memperkaya kandungan oksigen dalam ruang (Lazzerini et al, 2018) dan darah, serta mencegah infeksi Mycobacterium tuberculosis hingga $60 \%$ (Escombe et al, 2009). Mengambat infeksi Salmonella enteritidis hingga 96,5\% (Holt et al, 1999), mengurangi penyebaran virus Newcasle Disease di udara hingga 27,7 \% (Mitchell and King, 1994), mengurangi konsentrasi Porcine Reproductive and Respiratory Syndrome virus (PRRSV) antara 6896\% (La et al, 2019) dan dapat juga meningkatkan pertumbuhan tanaman selada (Song et al, 1994).

Kadar anion $1.000 / \mathrm{cm}^{3}-2.000 / \mathrm{cm}^{3}$ baik untuk kesehatan, $5.000 / \mathrm{cm}^{3}-50.000 / \mathrm{cm}^{3}$ dapat meningkatkan kekebalan tubuh, $50.000 / \mathrm{cm}^{3}-$ $100.000 / \mathrm{cm}^{3}$ dapat membunuh kuman dan mengurangi infeksi, kadar $100.000 / \mathrm{cm}^{3}$ $500.000 / \mathrm{cm}^{3}$ dapat membantu tubuh dalam proses penyembuhan alami (Lin et al, 2015).

Saat ini aktivitas perkantoran, bisnis, perdagangan, hotel, mall akan segera dimulai dengan ketentuan (protokol) yang berbeda yaitu dengan lebih peduli pada lingkungan, selalu 
menggunakan masker, rajin mencuci tangan, olah raga teratur, makan makanan bergizi, membatasi kerumunan dan selalu menjaga jarak serta memperbaiki dan perlunya meningkatkan kualitas udara di ruang perkantoran, rumah dan di dalam kendaraan agar tetap sehat, bersih, dan bebas VBKJP (virus, bakteri, kuman, jamur dan polusi).

Memanfaatkan anion dan dengan mengkondisikan lampu-UV di dalam Chamber merupakan salah satu upaya untuk menghasilkan udara yang bersih, sehat dan serta steril yang dapat mencegah penyebaran virus, melalui sirkulasi dan kekuatan kipas/blower. Pada saat kebiasaan baru perlu diterapkan peralatan dari aplikasi teknologi yang mampu menghasilan anion high density dengan kombinasi UV-Chamber (Jiang et al, 2018).

Tabel 1. Manfaat Anion dari hasil Penelitian

\begin{tabular}{|c|c|c|c|}
\hline No & Manfaat & $\begin{array}{c}\text { Kandungan } \\
\text { anion/cm3 }\end{array}$ & Reference \\
\hline 1 & $\begin{array}{l}\text { Baik untuk } \\
\text { kesehatan }\end{array}$ & $1.000-2.000$ & $\begin{array}{l}\text { Lin et al, } \\
2016\end{array}$ \\
\hline 2 & $\begin{array}{l}\text { Mencegah } \\
\text { Penyakit }\end{array}$ & $\begin{array}{l}5.000- \\
10.000\end{array}$ & $\begin{array}{l}\text { Wang et al, } \\
2010\end{array}$ \\
\hline & $\begin{array}{l}\text { an } \\
\text { kekebalan } \\
\text { tubuh }\end{array}$ & $\begin{array}{l}5.000- \\
50.000\end{array}$ & $\begin{array}{l}\text { Lin et al, } \\
2016\end{array}$ \\
\hline 4 & $\begin{array}{l}\text { Membunuh } \\
\text { bakteri }\end{array}$ & 50.000 & $\begin{array}{l}\text { Kellogg, } \\
1984\end{array}$ \\
\hline 5 & $\begin{array}{l}\text { Membunuh } \\
\text { kuman }\end{array}$ & $\begin{array}{l}50.000- \\
100.000\end{array}$ & $\operatorname{Lin}_{2016}$ et al, \\
\hline 6 & $\begin{array}{l}\text { Membantu } \\
\text { proses } \\
\text { penyembu } \\
\text { han alami }\end{array}$ & $\begin{array}{c}100.000- \\
500.000\end{array}$ & $\begin{array}{l}\text { Lin et al, } \\
2016\end{array}$ \\
\hline
\end{tabular}

Dalam kondisi kebiasaan baru diperlukan udara yang bersih dan sehat serta steril dalam ruangan perkantoran, mall-mall, termasuk rumah, dan di dalam kendaraan bermotor (mobil, bus dan kereta). Fasilitas umum, rumah sakit, transportasi umum termasuk di dalam kendaraan pribadi dan perumahan.

Teknologi Covid Buster dirancang untuk dapat menghasilkan anion agar udara bersih dan sehat serta steril dan dapat dipasang dimanapun sesuai dengan kebutuhan dengan kombinasi uv dan anion high density antara 20100 juta anion, sebagai sumbernya.

Rancangan saat ini diperuntukan untuk ruang perkantoran yang meliputi ruang kerja pimpinan, ruang kerja staf, ruang rapat, dan peralatan yang dirancang disesuaikan dengan kebutuhan luas ruangan dan jumlah orang di dalam ruangan.

\section{METODE PENELITIAN}

Metode penilitian ini terdiri dari desain, rancang bangun, pembuatan peralatan dan uji coba peralatan. Desain peralatan didasarkan dua teknologi utama yaitu ion generator dan alat penghasil sinar UV. Perhitungan kapasitas produksi ion dan sinar UV disesuaikan dengan volume ruangan yang akan dilakukan uji coba. Peralatan diuji cobakan di ruangan Direktur Utama PT. Adhi Karya di Jakarta. Kemudian dilakukan pengukuran kapasitas ion yang dihasilkan dan juga pengukuran ozon yang dihasilkan.

\section{HASIL DAN PEMBAHASAN}

\subsection{Standar Udara Dalam Ruang}

Peraturan Menteri Kesehatan No. 1077 tahun 2011 tentang Pedoman Penyehatan Udara Dalam Ruang Rumah dan Peraturan Gubernur Propinsi Daerah Khusus Ibukota Jakarta No. 54 Tahun 2008, Tentang Baku Mutu Kualitas Udara Dalam Ruangan (KUDR), tentang standar udara dalam ruangan.

Tabel 2. Lampiran Peraturan Menteri Kesehatan No. 1077 Tahun 2011

\begin{tabular}{|c|c|c|}
\hline \multicolumn{3}{|c|}{ Persyaratan Kimia } \\
\hline Jenis Parameter & $\begin{array}{c}\text { Kadar } \\
\text { maksimal }\end{array}$ & Keterangan \\
\hline $\mathrm{SO}_{2}(\mathrm{ppm})$ & 0,1 & 24 jam \\
\hline $\mathrm{NO}_{2}(\mathrm{ppm})$ & 0,04 & 24 jam \\
\hline $\mathrm{CO}(\mathrm{ppm})$ & 9,00 & 8 jam \\
\hline $\mathrm{CO}_{2}(\mathrm{ppm})$ & 1000 & 8 jam \\
\hline $\mathrm{Pb}\left(\mu \mathrm{g} / \mathrm{m}^{3}\right)$ & 1,5 & 15 menit \\
\hline Asbes (serat/ml) & 5 & $\begin{array}{l}\text { Panjang } \\
\text { serat } 5 \mu\end{array}$ \\
\hline $\begin{array}{l}\text { Formaldehid } \\
(\mathrm{HCHO})(\mathrm{ppm})\end{array}$ & 0,1 & 30 menit \\
\hline $\begin{array}{l}\text { Volatile Organic } \\
\text { Compound } \\
\text { (VOC) (ppm) }\end{array}$ & 3 & 8 jam \\
\hline $\begin{array}{l}\text { Environmental } \\
\text { Tobaco Smoke } \\
\text { (ETS) }\left(\left(\mu \mathrm{g} / \mathrm{m}^{3}\right)\right.\end{array}$ & 35 & 24 jam \\
\hline
\end{tabular}




\begin{tabular}{ccc}
\hline \multicolumn{2}{c}{ Persyaratan Kontaminan Biologi } \\
\hline $\begin{array}{c}\text { Jenis } \\
\text { Parameter }\end{array}$ & Satuan & $\begin{array}{c}\text { Kadar } \\
\text { maksimal }\end{array}$ \\
Jamur & $\mathrm{CFU} / \mathrm{m}^{3}$ & 0 \\
Bakteri patogen & $\mathrm{CFU} / \mathrm{m}^{3}$ & 0 \\
Angka kuman & $\mathrm{CFU} / \mathrm{m}^{3}$ & $<700$ \\
\hline
\end{tabular}

Tabel 3. Lampiran Peraturan Gubernur DKI Jakarta Nomor 54 Tahun 2008

\begin{tabular}{|c|c|c|}
\hline Parameter & Satuan & Baku Mutu \\
\hline KIMIA & & \\
\hline Oksigen $\left(\mathrm{O}_{2}\right)$ & $\%$ & $19,5-22,0$ \\
\hline $\begin{array}{l}\text { Karbon Monoksida } \\
\text { (CO) }\end{array}$ & $\begin{array}{l}\mathrm{ppm} / 8 \\
\text { jam }\end{array}$ & Maks. 8,0 \\
\hline $\begin{array}{l}\text { Karbon Dioksida } \\
\left(\mathrm{CO}_{2}\right)\end{array}$ & $\%$ & Maks. 0,1 \\
\hline $\begin{array}{l}\text { Mikrobiologi } \\
\text { Angka Kuman }\end{array}$ & Koloni/m³ & Maks. 700 \\
\hline
\end{tabular}

\subsection{Teknologi Covid Buster}

Peningkatan kualitas udara dalam ruangan kerja menjadi salah satu solusi bagi pekerja untuk berkarya, berinovasi dan memberikan pelayanan kepada konsumen dibutuhkan udara yang bersih dengan kadar anion yang cukup sesuai dengan luas ruangan dan jumlah pekerja yang ada di dalam ruangan.

Teknologi covid buster hasil inovasi untuk menghasilan anion dalam jumlah yang cukup untuk menghambat penularan virus covid19 dan akhirnya virus tidak berkembang sehingga pekerja di dalam ruangan terhindar dari pencemaran.

Permenkes PMK No. 1077 Tahun 2011 tentang Pedoman Penyehatan Udara Dalam Ruang Rumah dan Peraturan Gubernur Provinsi DKI Jakarta No. 54 Tahun 2008 tentang Baku Mutu Kualitas Udara Dalam Ruangan (KUDR), menjadi syarat minimal yang harus dipenuhi agar ruangan dalam udara menjadi sehat.

Peralatan Buster Covid Teknologi yang dirancang harus minimal memenuhi kebutuhan anion pada kedua peraturan tersebut. Rancangan teknologi covid buster diharapkan dapat menghasilkan kadar anion mencapai 100.000 - 500.000 agar dapat membantu tubuh dalam proses penyembuhan sendiri, yang ada di dalam ruangan kerja pada perkantoran.

Prinsip Kerja Teknologi Covid Buster menghasilkan anion (ion negative) yang dapat merusak virus, jamur dan bakteri dengan prinsip kerja sebagai berikut :

1. Emisi ion semburan plasma menghasilkan dan melepaskan ke udara ion positif dan ion negatif yang sama seperti yang ada pada alam.

2. Efek terhadap jamur dan virus, saat bersentuhan dengan permukaan spora, jamur, bakteri atau virus, ion - ion akan berubah menjadi radikal $\mathrm{OH}^{-}$dengan sifat pengoksidasi yang sangat kuat. Radikal $\mathrm{OH}^{-}$ ini langsung berekasi dengan Hidrogen $\mathrm{H}^{+}$ dari protein pada permukaan jamur, virus atau bakteri, sehingga struktur protein rusak.

3. Ion berubah menjadi air dan kembali ke udara, penggabungan radikal $\mathrm{OH}^{-}$dengan hidrogen $\mathrm{H}^{+}$menghasilkan air $\mathrm{H}_{2} \mathrm{O}$ dan kembali ke udara.

\subsection{Rancangan Teknologi Covid Buster untuk ruangan}

Peralatan Teknologi Covid Buster dirancang untuk merusak protein virus dan juga menyaring mikroorganisme pathogen dari aliran udara, sehingga udara di dalam ruangan kerja menjadi bersih, sehat dan bisa memulihkan kondisi orang yang sedang sakit.

Peralatan dirancang dengan menggabungkan filtrasi dan inaktivasi mikroorganisme pathogen di udara yang akhirnya akan menghasilkan udara yang steril dan bersih secara lebih efisien.

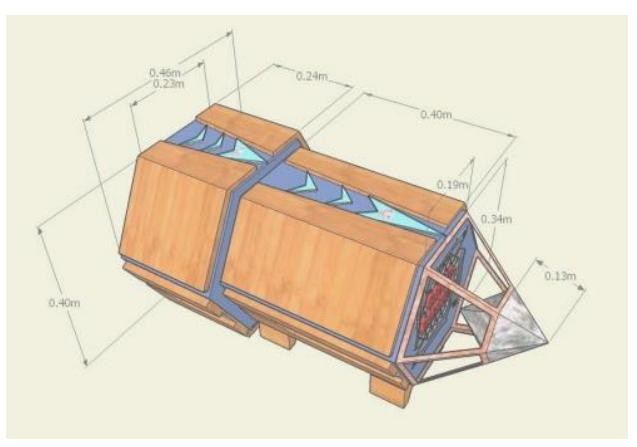

Gambar 2. Peralatan Covid Buster

Peralatan Covid Buster yang dirancang terdiri dari 3 unit, yaitu sebagai berikut :

1. UV Chamber, sebagai alat untuk mensterilkan udara yang akan dialirkan kedalam unit Air Purifier.

2. Air Purifier, sebagai alat yang mampu memfilter kualitas udara yang kurang baik, dengan menggunakan produk yang ada dipasaran, dimana didalamnya telah dimodifikasi dengan penambahan unit ion generator.

3. Anion Generator, telah dirancang untuk memproduksi kandungan anion yang cukup 
besar (rentang 500.000 hingga 2 juta anion $\left./ \mathrm{cm}^{3}\right)$, yang juga memiliki kandungan ozone (berfungsi mampu membasmi virus) pada batas yang telah ditetapkan Kemenkes yaitu dibawah 0.1 ppm.

Peralatan Covid Buster dirancang untuk memiliki kemampuan memproduksi kandungan anion (ion negatif) maksimal : $1.999 \times 107$ (19 juta anion $/ \mathrm{cm}^{3}>$ sumber alat) \& pada jarak 3-6 meter masih memiliki kandungan 1-5 juta/ $\mathrm{cm}^{3}$, sementara kualitas udara setara pada kawasan air terjun Niagara hanya memiliki 600.000 anion.

Untuk kesehatan sehari-hari secara normal hanya mendapatkan 10.000 - 50.000 anion (sangat minimal). Agar tubuh kita sehat dan terhindar dari virus dan patogen, harus mendapatkan kandungan 100.000 - 600.000 anion $/ \mathrm{cm}^{3}$.

Lebih dari itu pada ruang isolasi pasien positif covid harus memiliki kandungan anion $600.000 / \mathrm{cm}^{3}$.

Perlu kita ketahui bahwa terdapat bakteri dan virus yang jahat, demikian juga ada ion jahat (kation/ion+) dan ion baik (anion/ion-) yang berterbangan di udara dalam ruangan.

Anion Generator mampu memproduksi ion negatif dengan target membasmi bakteri, kuman dan virus yang terdapat di ruangan hingga ke dalam tubuh manusia yang menghirupnya. Artinya ion negatif sangat baik untuk manusia, terutama untuk pasien covid.

Desain penempatan peralatan Covid Buster Teknologi di ruangan kerja Direktur Utama PT. Adhi Karya, dipasang 3 unit peralatan Covid Buster, letak peralatan seperti pada desain gambar di bawah ini :

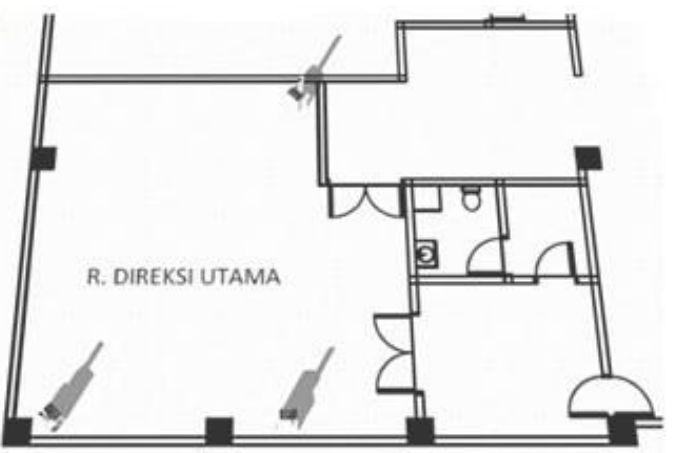

Gambar 3. Lay-out Alat Covid Buster di ruangan Dirut PT. Adhi Karya, Jakarta

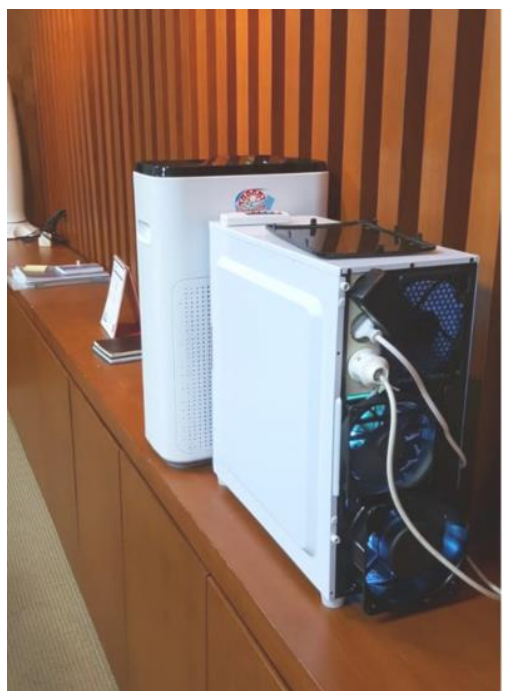

Gambar 4. Peralatan Covid Buster di ruangan Dirut PT. Adhi Karya, Jakarta

Dalam ujicoba alat Covid Buster telah dilakukan pengukuran dengan alat ukur Anion Meter dan hasil analisa laboratorium kandungan ozon.

Peralatan covid buster yang telah dihasilkan dari penyempurnaan inovasi produk dalam negeri, yaitu:

1. Model Piramida

Dirancang menghasilkan anion sebesar 10 juta/ $\mathrm{cm}^{3}$. Telah diujicobakan di rumah sakit untuk menghasilkan udara yang bersih.

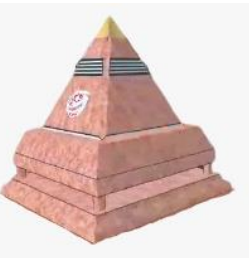

2. Model Ammara

Menghasilkan anion sebesar 5 juta $/ \mathrm{cm}^{3}$, cocok digunakan dalam ruangan perawatan kecantikan dan kesehatan

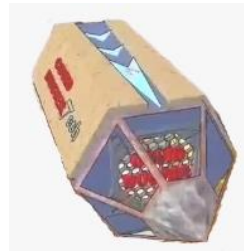

3. Model Uvion

Inovasi terbaru yang diselesaikan pada bulan Oktober 2020 dapat menghasilkan anion sebesar $100 \mathrm{juta} / \mathrm{cm}^{3}$

Cocok digunakan di ruangan rapat, ruangan kerja pimpinan, ruangan

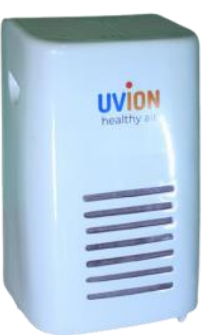


seminar, ruangan belajar

dan di tempat pesta.

\subsection{Hasil Pengujian Anion yang dihasilkan}

Peralatan Covid Buster yang telah dipasang pada ruangan kerja Dirut PT. Adhi Karya menghasilkan anion lebih dari 500.000 per $\mathrm{cm}^{3} /$ detik. Peralatan tersebut digunakan untuk ruangan seluas dengan panjang 12 meter dan lebar 10 meter, telah menghasilkan udara di ruangan yang steril dan sehat.

Peralatan covid buster mampu memproduksi Anion (high density) sebesar 20100 juta anion $/ \mathrm{cm}^{3}$ per detik.

Pada proses pengembangan atau inovasi produksi, dihasilkan 3 prototipe yaitu Model Piramida, Model Ammara dan Model Uvion. Peralatan covid buster model Piramida menghasilkan anion sebesar $10 \mathrm{juta} / \mathrm{cm}^{3}$, dirancang untuk ruangan keluarga, ruangan kamar tidur agar udara yang dalam ruangan dan kamar bersih dan sehat.

Peralatan model Ammara dirancang untuk ruangan perawatan kesehatan atau kecantikan dengan anion yang dihasilkan sebesar 5 juta/ $\mathrm{cm}^{3}$,

Rancangan terbaru peralatan covid buster yang dinamakan dengan Model Uvion mampu menghasilkan anion sebesar $100 \mathrm{juta} / \mathrm{cm}^{3}$, yang merupakan produk dalam negeri dengan kemasan yang lebih baik lagi.

Jumlah anion yang dihasilkan melebihi kebutuhan untuk pemulihan kesehatan pada umumnya sehingga diharapkan memberikan kenyaman bagi pekerja, pasien, dokter dan petugas medis karena udara steril (bersih) dari virus, bakteri dan jamur serta polusi, juga dapat memulihkan pekerja, pasien dan setiap orang yang terserang sakit bagian pernafasan, termasuk influensa sudah terbukti dan walaupun belum diujicobakan pada virus covid-19, berdasarkan literatur yang ada bahwa anion dapat merusak protein pada corona virus yang mengakibatkan fungsinya menjadi rusak dan tidak lagi menyebabkan positif corona.

Testimoni beberapa orang yang telah menggunakan peralatan covid buster mengatakan bahwa pemulihan lebih cepat dari flu, batuk dan alergi.

\section{KESIMPULAN}

Teknologi Covid Buster menghasilan kadar Anion 1-100 juta $\mathrm{cm}^{3} /$ detik, sesuai dengan penelitian dan pengujian beberapa ahli, yang jauh lebih dari cukup, dan diharapkan dapat menetralisir virus, termasuk covid-19.

Teknologi Covid Buster dapat diterapkan di dalam ruangan kerja dengan ruangan sebesar $10 \times 12$ meter $^{2}$. Anion telah terbukti mampu menyediakan udara yang sehat, meningkatkan kekebalan tubuh dan membunuh virus, bakteri dan kuman, jamur serta polusi.

Teknologi Covid Buster cocok diletakkan dalam ruangan kerja, agar pimpinan dan karyawan tetap bisa bekerja sehingga produkfivitas tetap bisa dipertahanan dalam kebiasaan baru saat ini, hingga vaksin bisa ditemukan.

Telah dilakukan ujicoba di ruangan ditrektur PT Adhi Karya Jakarta dan memberikan dampak positif terhadap karyawan yang ada, mempercepat pemulihan flu, batuk dan alergi.

Peralatan covid buster telah digunakan pada ruang perawatan kesehatan atau kecantikan, di ruangan tamu dan ruangan kamar, serta di ruang rapat, yang telah terbukti menyegarkan orang yang berada dalam ruangan tersebut.

\section{SARAN}

Teknologi Covid Buster dapat diujicobakan langsung di ruangan ICU, perawatan pasien Covid-19, dan rumah sakit tempat rujukan, agar menghasilkan udara yang sehat, bersih dan ramah lingkungan serta dapat membasmi berbagai macam kuman penyakit yang ada di ruangan dan menyegarkan bila dihirup oleh petugas kesehatan, pekerja dan pasien.

\section{UCAPAN TERIMA KASIH}

Kami mengucapkan terimakasih terutama kepada Direksi dan staf PT. Adhi Karya Jakarta yang telah membantu dalam pelaksanaan ujicoba peralatan Covid Buster.

\section{DAFTAR PUSTAKA}

Doremalen, N.V.; Bushmaker, T.; Morris, D.H.; Holbrook, M.G.; Gamble, A.; Wiliamson, B.N.; Tamin, A.; Harcourt, J.L.;Thornburg, N.J.; Gerber, S.I.; Smith, J.O.L.; Wit, E.D. and Munstr, V.J. (2020). Aerosol and Surface Stability of SARS-CoV-2 as Compared with SARS-CoV-1. The New England Journal of Medicine. 382;16 April 16. 
Escombe, A.R.; Moore, D.A.; Gilman, R.H.; Navincopa, M.; Ticona, E.; Mitchell, B.; Noakes, C.; Martínez, C.;Sheen, P.; Ramirez, R.; et al (2009). Upper-room ultraviolet light and negative air ionization to prevent tuberculosis transmission. PLOS Med. Vol.6, Issue 3.

Goldstein, N. (2002). Reactive Oxygen Species as Essential components of Ambient Air. Biochemistry Vol. 67, No. 2. Pp 161-170

Holt, P.S., Mitchell, B.W., Seo, K.H. and Gast, R.K. (1999). Use of Negative Air Ionization for Reducing Airborne Levels of Salmonella Enterica serovar enteridisin a Room Containing Infected Caged Layers. Journal of Applied Poultry Research.8:440-446.

Jiang,S.Y.; Ma, A and Ramachandran, S. (2018). Review Nagative Air lon and Their Effects on Human Health and Air Quality Improvement. International Journal of Molecular Sciences. 19, 2966.

Jin, Y.; Yang, H.; Ji, W.; Wu, W.; Chen, S.; Zhang, W. and Duan, G. (2020). Review Virology, Epidemology, Pathogenesis, and Control of COVDI-19. Viruses, 12, 372.

Kellogg, E.W. (1984). Air ions: Their possible biological significance and effects. Journal of Bioelectricity. 3(1-2):119-136.

Krueger, A.P and Reed, E.J. (1976). Biological impact of small air ions. Science. 193, 1209-1213.

La, A., Zhang, Q., Levin, D.B. and Coombs, K.M. (2019). The Effectiveness of Air lonization in Reducing Bioaerosls and Airborne PRRS Virus in a Ventilated Space. Transactions of the ASABE Vol. 62(5): 1299-1314.

Lazzerini, F.T.; Orlando, M.T.; De Prá, W. (2018). Progress of negative air ions in health tourism environments applications. Bol. Soc. Esp. Hidrol. Méd. 33, 27-46.

Lin, M.Z., Ji, S.T., Zhao, J.L. and Fang, B.Z. (2016). Evaluation on environment quality of Bai-Yun mountain scenic area. Proceeding of the 2015 International Conference on Sustainable Development. World Scientific Publishing Co. Pte. Ltd

Mitchell, B.W. and King, D.J. (1994). Effect of Negative Air Ionization on Airborne
Transmission of Newcastle Disease Virus. Avian Disesase 38:725-732.

Setti, L.; Passarini, F.; Gennaro, G.D.; Barbieri, P.; Perrone, M.G.; Berelli, M.; Palmisani, J.; Gilio, A.D.; Piscitelli, P. and Miani, A. (2020). Airborne Transmission Route of COVID-19: Why 2 Meters/6 Feet of InterPersonal Distance Could Not Be Enough. International Journal of Environmental Research and Public Health. 17, 2932.

Song, M.J., Kang, T.H., Han, C.S. and Oh, M.M. (2014). Air Anion Enhances Lettuce Growth in Plant Factories. Hort. Environ. Biotechnol. 55(4):293-298.

Stroud, C.L. (2009). Negative lons Yield Positive Attitudes. The ASPPA Journal. Vol.39, No.2.

Tikhonov, V.P.; Temnov, A.A.; Kushnir, V.A.; Tetyana, V.S.; Litvinova, E.G.; Zakharchenko, M.V. and Kondraskova, M.N. (2004). Complex Therapeutical Effect of Ionized Air: Stimulation of Immune System and Decrease in Excessive Serotonin. $\mathrm{H}_{2} \mathrm{O}_{2}$ as a link between the Two Counterparts. IEEE TRANSACTIONAL ON PLASMA SCIENCE, Vol.32, No. 4, August

Wang X, Li Q, Liu L, Ma W. (2010). The study of the distribution and forecasting of air anion concentration in Qinhuangdao, China. Second IIT A International Conference on Geoscience and Remote Sensing. 2010; 354-356.

Wu, Y.; Jing, W.; Liu, J.; Wang, Y.; Du, M and Liu, M. (2020). Effects of temperature and humidity on the daily new cases and new deaths of COVID-19 in 166 countries. Science of Total Environment 729, 139051.

Xie, X., Li, Y., Chwang, A.T.Y., Ho, P.L., and Seto, W.H. (2007). How far droplets can move in indoor environments-revisiting the Wells evaporation-falling curve. Indoor Air. 17:211-225.

Zhu, N.; Zhang, D.;Wang,W.; Li, X.; Yang, B.; Song, J.; Zhao, X.; Huang, B.; Shi,W.; Lu, R. et al; (2020). A Novel Coronavirus from Patients with Pneumonia in China, 2019. N. Engl. J. Med. Feb 20; 382(8): 727-733. 
